Economics and Finance in Indonesia

Vol. 61 No. 1, $2015: 53-68$

p-ISSN 0126-155X; e-ISSN 2442-9260

\title{
Indonesia's Dynamic Electricity Power Sector: Investigating Need and Supply Performance
}

\author{
Latif Adam ${ }^{\mathrm{a}, *}$, Maxensius Tri Sambodo ${ }^{\mathrm{a}, * *}$ \\ a Indonesian Institute of Sciences (LIPI)
}

\begin{abstract}
This paper analyzes the development and problems of electricity sector in Indonesia. After the economic crisis of 1997/98, investment in power sector has been decreasing. Minimizing transmission and distribution loss can increase reliability and quality of power supply, improve financial capacity, and reduce electricity subsidy. Electrification ratio and electric power consumption per capita need to be improved equally among provinces. Promoting public private partnership (PPP) can boost investment. Main policy challenges need to be addressed are that government needs to (1) provide information on the investment prospects; (2) solve social aspect of the project; and (3) provide practical guide in land acquisition.
\end{abstract}

Keywords: Electricity; Public Private Partnership; Policy Challenges

\begin{abstract}
Abstrak
Tulisan ini menganalisa perkembangan dan permasalahan sektor kelistrikan di Indonesia. Setelah krisis ekonomi 1997/98, investasi di sektor energi cenderung menurun. Meminimisasi kerugian transmisi dan distribusi dapat meningkatkan keandalan dan kualitas pasokan daya, meningkatkan kapasitas keuangan, dan mengurangi subsidi kelistrikan. Rasio elektrifikasi dan konsumsi daya listrik per kapita perlu ditingkatkan secara merata antar provinsi. Pengupayaan Public Private Partnership (PPP) berpeluang meningkatkan investasi. Tantangan kebijakan utama yang perlu diatasi adalah bahwa pemerintah perlu (1) menyediakan informasi atas prospek investasi; (2) mengantisipasi pengaruh sosial dari proyek; serta (3) menyediakan panduan praktis tentang perolehan lahan.
\end{abstract}

Kata kunci: Kelistrikan; Kemitraan Publik Swasta; Tantangan Kebijakan

JEL classifications: $010,020, Q 40$

\section{Introduction}

Electricity has an important role to accelerate economic development of a country. This sector could play as input of production and has a high multiplier effect to facilitate and stimulate the development of other economic sectors. Several studies indeed concluded that electricity is a fundamental element to achieve multi economic development goals, including creating employment, generating income, transforming economic structure and im-

${ }^{*}$ Corresponding Address: Jend. Gatot Subroto Street No. 10, Jakarta 12710 E-mail: latif_adam@yahoo.com.au.

**Visiting Fellow at Institute of Southeast Asian Studies (ISEAS). E-mail: smaxensius@yahoo.com; maxensius .tri. sambodo@lipi.go.id; maxensius_sambodo@iseas.edu.sg. proving people welfare (Wallace 2008; Arief 2011; Adam 2012).

Despite playing an important role, the development of electricity in Indonesia still lags far behind that in several Indonesia Asian neighbours. Accordingly, there has been an electricity shortage in the Indonesian economy, as indicated by relatively low level of electrification ratio. The World Development Indicators shows that in 2011, electrification ratio in Indonesia was about $71.2 \%$, lower than that in Singapore (100\%), Malaysia and Brunei (85\% each). The Indonesian electrification ratio of $71.2 \%$ suggets that there was $28.8 \%$ of Indonesia total household who have no access to electricity. Moreover, many provinces, particularly in Eastern part of Indonesia, have electrification ratio of below $50 \%$, such as East Nusa Tenggara in which 
its electrification ratio was only $34.5 \%$ (PT PLN (Persero) 2011).

Furthermore, according to the World Energy Investment Outlook 2003 (IEA 2003), over the thirty years period of 1971-2000, additional capacity of the Indonesia's electricity sector was the lowest compare to those of China and India. This indicates that there is a problem in investment especially after the Asian economic crisis of 1997/98. One of the main obstacles to improve the Indonesia's electricity sector is underinvestment in power supply (IEA 2008). Since the economic crisis of 1997/98, the newly installed capacity of PT Perusahaan Listrik Negara (National Electricity Company-PT PLN (Persero)) has showed a decreasing growth rate from $10.4 \%$ between 1990 and 1997 to $2.1 \%$ between 1998 and 2007 (Sambodo \& Oyama 2010).

Electricity shortage adversely affected business environment as it increases cost of doing business in Indonesia. Due to lack in electricity supply, access to electricity becomes expensive. Several studies (e.g. Wold Bank 2005; International Finance Corporation 2011; World Economic Forum 2012) indeed shows that electricity cost in Indonesia was relatively higher than that in Malaysia, Thailand, and China (Wold Bank 2004; International Finance Corporation (IFC) 2011; World Economic Forum 2012). Moreover, a World Bank study (2004) revealed that of 900 companies surveyed, they lost $6 \%$ of their total sale per year due to electricity and energy problems.

The main purpose of this paper is to analyze the development and problems of electricity sector in Indonesia. This paper will also investigate the implementation of public private partnership (PPP) in the electricity sector as an alternative solution to improve performance of the sector. Based on these findings, this paper derives policy implications of what should the government and other stakeholders do to develop electricity successfully.

\section{Analysis}

As noted previously, the development of electricity in Indonesia still lag behind that in several Asian countries. Indeed, as shown in Figure 1, in terms of electricity production per capita, Indonesia stays behind China, Malaysia, and Vietnam. However, in 2010, electricity production per capita in Indonesia was slightly higher than that in India. Interestingly, between 2008 and 2010, electricity production per capita in China, Malaysia, and Vietnam, increased rapidly, while in India, Indonesia, and Thailand only increased marginally. Low level of electricity production per capita indicates that part of communities depend on traditional energy sources and off grid power connections that have not been recorded by administrators.

The production of electricity in Indonesia as a ratio of the production of electricity in several Asian countries, such as China and India, is also relatively small. This is an indication that Indonesia has a relatively less capacity to produce electricity than those in several Asian countries. For example according to the World Development Indicators, in 2010 , the production of electricity in Indonesia was about 170 TWh, while China and India were about 4,208 TWh and 560 TWh respectively. Thus, the production of electricity in Indonesia as a ratio to that in China and India is about $17.3 \%$ and $4.2 \%$ respectively (Figure 2).

Figure 2 also showed that between 1971 and 2001 there had been an increase in the production of electricity in Indonesia as a ratio to that in China and India. However, since 2001, the production of electricity in Indonesia as a ratio to China has decreased, while ratio to India remained constant. This suggest that since 2001, China has become more expansive to produce electricity than Indonesia.

As noted previously, lack of capability to generate sufficient electricity supply might hamper Indonesia to improve its competitiveness to attract more investment. This is particularly true as electricity is an important requirements to maintain and increase a competitive investment climate through its role in facilitating improvement in efficiency and productivity. The fact that China has a better capability in providing electricity than Indonesia has resulted in a condition that China is more successful than Indonesia in attracting investment, particularly those in energy intensive industries.

The significant improvement in the capability of China to provide electricity supply could be attributed to the power sector reform in 2002 that has encouraged positive attitude for vigorous competition in power supply. IEA (2005) highlighted 


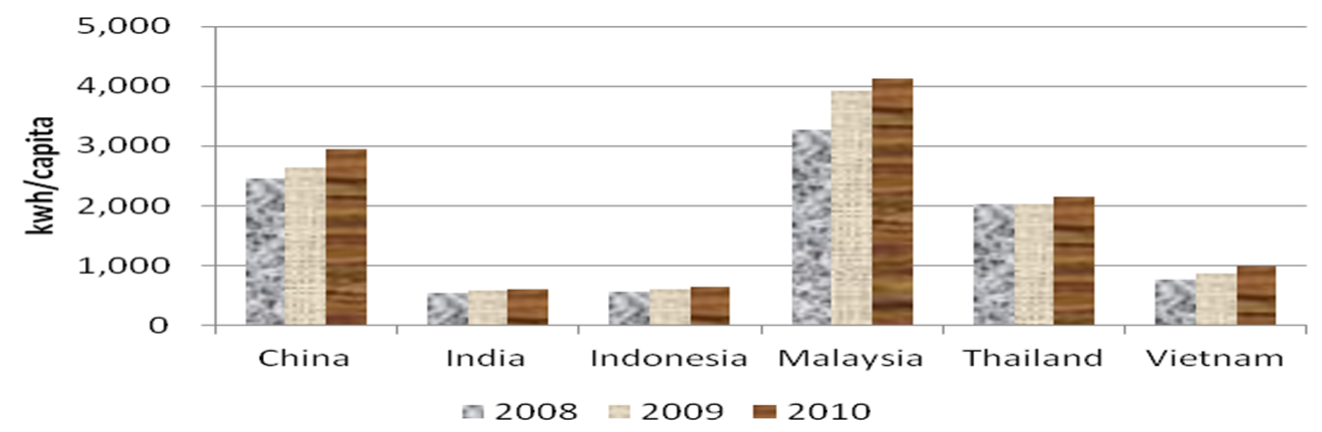

Figure 1: Electricity Production per Capita

Note: We deducted electricity production with transmissions and distribution loss.

Source: World Development Indicators, Various Issues

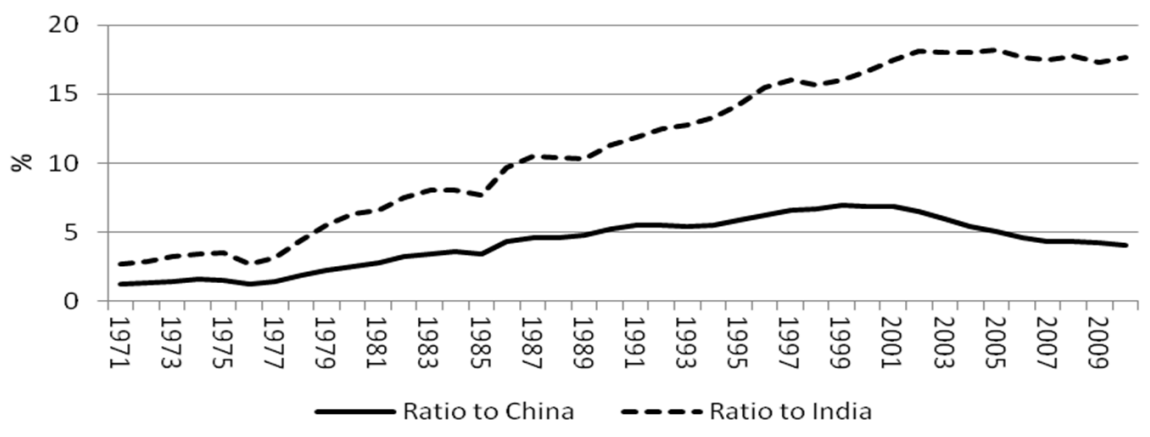

Figure 2: Ratio of Indonesia's electricity production to China and India (1971-2010) Source: World Development Indicators

three important elements of this power reform. First, China split vertically integrated utility to two grid companies with several set of generating companies. Second, China implemented competitive power market for selected regions. Third, China developed State Electricity Regulatory Commissions (SERC) as an independent regulatory. Contrastingly, in Indonesia, the Constitutional Court annulled the Electricity Law No 20/2002. It was believed that the law can create more competitive power market in Indonesia. This suggests that the cancellation of this Electricity Law might discourage Indonesia to improve its capability in providing electricity supply.

The lack of capability to provide sufficient electricity supply also resulted in Indonesia having low electricity consumption per capita. For example, in 2010 , electricity consumption per capita in China reached 2,944 $\mathrm{kWh}$, while in Indonesia and India only reached $641 \mathrm{kWh}$ and $616 \mathrm{kWh}$ respectively (Figure 3). Surprisingly, Indonesia can catch up India in 2000 and since then electricity consumption in Indonesia is higher than that in India. If electricity consumption per capita is used to measure people's welfare, Figure 3 suggests that welfare of Indonesian is worse than that of Chinese, but it is slightly better than that of Indian.

We calculate electricity intensity or ratio of electricity consumption to GDP (Figure 4). If the intensity increases, we consume more electricity to produce one unit of GDP. Reduction in energy intensity can be caused by several factors such as production shift to high value added products, improving in technology, and changing in the government policy toward energy used (Sambodo \& Oyama 2011a). In the case of China, electricity intensity tended to decrease between the mid-1980s to early 2000, and then it had increased continuously since 2000s. Bergsten et al. (2009) pointed the dramatic increase in China's energy consumption to a rise in its heavy industries, such as flat glass, cement, steel, and aluminum. These industries have developed because of several factors: low operating cost, low labor cost, high profits, eco- 


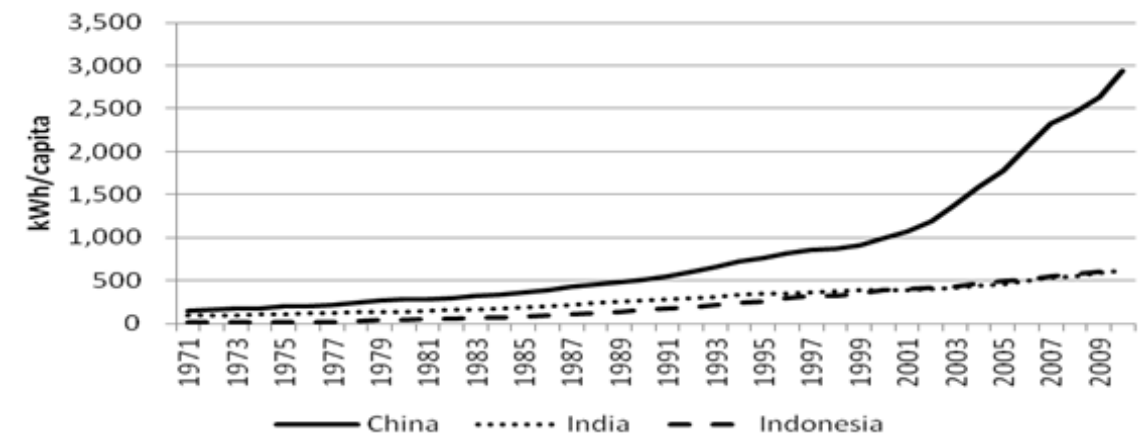

Figure 3: Electricity Consumption per Capita (1971-2010)

Source: World Development Indicators

nomic incentives from local governments, and the ease of obtaining credit from the banks (Bergsten et al. 2009).

In the case of India, electricity intensity has decreased since the early 1990s. We argued that this is mainly driven by rapid increase in services sector that require less energy than manufacturing sector. In the case of Indonesia, the intensity has remained constant since 2000. In Indonesia, electricity intensity is relatively low due to some industries substitute their energy or reduces electricity consumption from PT PLN (Persero) to non PT PLN (Persero) through constructing their own power supply (Sambodo \& Oyama 2011b). There are three main reasons why many industries construct their own power plants; obtaining lower cost, improving quality and quantity of power supply, and selling extra power to PT PLN (Persero).

Although electricity production can grow in a higher rate than its consumption, it does not mean that the quantity and quality of electricity supply can adequately meet its demand. This is because there are some losses during transmissions and distribution process before the electricity could finally be delivered and enjoyed by consumers. It can be seen from Table 1, transmission and distribution loss (TDL) in Indonesia actually tends to decrease from about $10 \%$ in 2008 to about $9.4 \%$ in 2010 . However, in comparison with several Asian countries, except with India and Vietnam, TDL in Indonesia is still relatively high, suggesting that there is a potential efficiency gain by minimizing TDL. By assuming Indonesia can reduce TDL from $9.4 \%$ to about $6 \%$, the amount of electricity subsidy can be reduced by $7 \%{ }^{1}$.

To understand TDL, it is important to know how the power is delivered to the consumers. Between the power plant and consumers, there are step up substations and step down substations. Step up substation uses high voltage overhead lines to reach step down substation, while medium or low voltage transformer link between step down substation and consumers. There are two sources of TDL, namely technical and commercial loss. Technical loss is due to energy dissipated in the conductors and equipment used for transmission, transformation, sub-transmission, and distribution of power, while commercial loss is because of pilferage, defective meters, and error in meter reading and in estimating unmetered supply of energy ${ }^{2}$. Investment on transmissions and distribution is a key to reduce TDL from the technical perspective. In the case of India theif and pilferage have substantial affect on TDL (Bhalla 2000).

Although increasing electricity production is important, the concept of low carbon economy also need to be considered. There are three core elements of low carbon economy from the energy sector perspective such as energy efficiency, energy saving and renewable energy (Hu et al. 2011). Following PT PLN (Persero)'s business plan of 20112020, there are four main strategies to promote green power investment. First, PT PLN (Persero)

\footnotetext{
${ }^{1}$ We used average selling price in 2010 that was about Rp699.09/kWh. The amount of electricity subsidy in 2010 was about Rp58.1 trillion or USD 5.8 billion (if USD $1=R p 10.000$ ).

${ }^{2} \mathrm{PLN}$ reports two type of losses namely transmissions and distribution losses. The two losses are technical loss. There is no systematic report to publish the commercial loss, but PLN frequently conduct market operation to reduce the pilferage.
} 


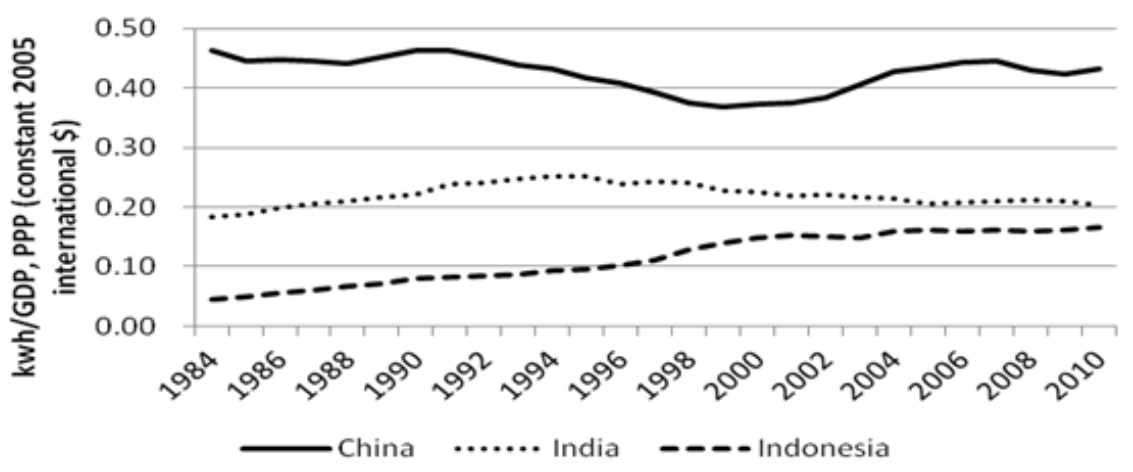

Figure 4: Electricity Intensity (1984-2010)

Source: World Development Indicators

Table 1: Transmissions and Distribution Loss (\%)

\begin{tabular}{lrrr}
\hline Country & 2008 & 2009 & 2010 \\
\hline China & 6.1 & 6.0 & 6.1 \\
India & 22.0 & 22.0 & 22.0 \\
Indonesia & 10.1 & 9.6 & 9.4 \\
Malaysia & 8.0 & 6.0 & 6.5 \\
Thailand & 6.1 & 5.9 & 6.3 \\
Vietnam & 10.1 & \multicolumn{1}{c}{9.6} & 10.1 \\
\hline Note: It reflects share of Electric \\
power transmission and \\
distribution losses (kWh) to \\
Electricity production (kWh). \\
Source: Author's Calculation
\end{tabular}

aims to enhace gas utilization. Second, new investment in renewable energy such as geothermal, solar panel, hydro-power is promoted. Even, now PT PLN (Persero) has applied feed in tariff for new and renewable energy sources. Third, new investment in supercritical and ultra-super critical has been implemented. This is important to enhance efficiency of steam coal power plants and to reduce CO2 emissions. Finally, demand side management is implemented by promoting energy saving. Similarly with China, $\mathrm{Hu}$ et al. (2011) mentioned that China was very successful to close $70 \mathrm{GW}$ small scale thermal generation units by the end of 2009 . The Chinese government has provided incentives to enhance efficiency on coal-fired power plants and subsidies for energy efficient light bulb and home appliances.

\subsection{PT PLN (Persero)'s Performance}

Table 2 shows the progress of the fast-track program based on existing data of 2010, four years after the starting of this program. It is important to bear in mind, that diesel and combined oil-gas are not part of the first and second fast-track programs. After the second fast-track program, the national electricity capacity will increase between 17,700 MW and 20,100 MW (between 57\% and $68 \%$ from the existing capacity in 2006). Evaluating the progress of the first fast-track program by using 2010 as the base year, Table 2 indicates that the achievement is still below the target, since the capacity increased by only 1,912 MW. The fasttrack program has not yet resulted in impressive achievement. According to PLN, there were several reasons for the delay of the project, such as land availability, shortage of cash, and delays in loan disbursements (PT PLN (Persero) 2009). It appears that only steam and combined gas-steam power plants showed a decrease.

Statistical evidence indicates that there has been a similar trend in the growth of electricity production and consumption in that it decreased overtime. For example, between 1971 and 1981, electricity production grew by about $17.2 \%$ per year. The growth 
Table 2: Changes in Installed Capacity Before and After the Fast-Track Program (in MW)

\begin{tabular}{|c|c|c|c|c|c|c|c|c|c|}
\hline No. & Year/Period & Hydro & Steam & Gas & $\begin{array}{l}\text { Combined } \\
\text { Gas-Steam }\end{array}$ & $\begin{array}{r}\text { Geo } \\
\text { Thermal }\end{array}$ & Diesel & $\begin{array}{r}\text { Combined } \\
\text { Oil-Gas }\end{array}$ & Total \\
\hline 1 & 2006 (Before the fast-track) & 3,532 & 12,990 & 2,727 & 7,895 & 800 & 3,001 & 12 & 30,958 \\
\hline 2 & After the I fast-track (2006-2009) & 3,532 & $20,690-24,112$ & 2,727 & 7,895 & 800 & 3,001 & 12 & $38,658-42,080$ \\
\hline 3 & After the II fast-track (2010-2014) & 4,736 & $23,902-27,324$ & 2,827 & 9,455 & 4,777 & 3,001 & 12 & $48,711-52,133$ \\
\hline 4 & Change (No. 3-No. 1) & 1,204 & $10,912-14,334$ & 100 & 1,560 & 3,977 & 0 & 0 & $17,753-21,175$ \\
\hline 5 & Installed capacity in $2010^{*}$ & 3,709 & 12,290 & 3,460 & 7,840 & 1189 & 4,343 & 38.8 & 32,870 \\
\hline 6 & Change between 2006-2010 & 117 & -700 & 733 & -55 & 389 & 1,341 & 27 & 1,912 \\
\hline
\end{tabular}

tends to decrease in the subsequent periods and it reached $6.1 \%$ between 2001 and 2011. Similar to the growth of electricity production, the growth of electricity consumption also tend to decline over the investigation periods (Table 3 ).

Table 3 also indicates that the growth of electricity production is consistently higher than that of consumption. In average, between 1971 and 2011 , electricity production and consumption grew by $12.3 \%$ and $12 \%$ per year respectively.

In addition to failure in providing sufficient electricity supply, Indonesia also face the problem of unequal power distribution among its regions. As indicated in Table 4, it is about $22,5 \mathrm{GW}$ or about $77 \%$ of Indonesia installed electricity capacity is located in Java island. Consequently, Java dominated both net electricity production and energy sold. Furthermore, electrification ratio in Java is higher than that in other islands. For example, in 2011, electrification ratio in Java reached $76 \%$, while that in outside Java only reached about $64 \%$.

It is important to note that electrification ratio tend to correlate significantly with electricity consumption per capita. The higher the electrification ratio in a province, the more probable this province to have a high electricity consumption per capita $(\text { Table } 5)^{3}$. As electrification ratio in Java is higher than that in outside Java, electricity consumption per capita in Java is also higher than that in outside Java. In 2011, electricity consumption per capita in Java accounted for about $854.4 \mathrm{kWh}$, while the figure in outside Java was only $392.2 \mathrm{kWh}$.

\footnotetext{
${ }^{3}$ In the case of Banten, it has relatively low electrification ratio but has it relatively high electricity consumption per capita, this is due more than $85 \%$ of electricity sold in Banten are for medium and high voltage who are mostly for commercial and industrial sectors. In contrast, $59.2 \%$ of electricity sold in central Java was consumed by low voltage or household sector.
}

Statistical evidence in Table $\mathbf{4}$ and 5 suggests that electricity shortage is more severe in Java than that in outside Java. Therefore, it is not surprising if demand for electricity is relatively higher in outside Java than that in Java. For example, in 2011, the number of customer waiting list in outside Java reached 120,166 with total power demand about 1,211,688.5 kVA, whereas in Java the number of customer waiting list reached 19,776 with total power demand about 195,577 kVA.

The fact that outside Java face more severe electricity shortage than that of Java might deter outside Java to catch its economic development up to that of Java, This might also impede efforts of the government to distribute and move out investment from Java to outside Java. This is because electricity is the key to facilitate, support and encourage investment, business activities and other economic activities.

Based on the aforementioned problems, promoting power plants investment could be a vital solution to reduce economic development discrepancy between Java and outside Java. In comparison with others infrastructure, several studies (e.g. Situmorang 2012; Adam 2012) showed that power plant investment has higher multiplier impact on the economy. For example, by applying the InputOutput Model, Adam (2012) showed that electricity has high multiplier output $(1,93)$, backward linkage $(\mathrm{BL})(1,10)$, and forward linkage $(F L)(1,04)$. Because $B L$ is above one, technically we can argue that an increase of one unit of final consumption in electricity sector will cause an increase of economic activities above the average increase due to one extra unit of final consumption in any other sectors. Similarly, FL indicates that an increase of one unit of production in electricity sector will cause an increase of economic activities above the average increase due to an extra unit production in any 
Table 3: Electricity Production and Consumption in Indonesia, 1971-2011

\begin{tabular}{lrr}
\hline & Production & Consumption \\
\hline Nominal (GWh) & & \\
1971 & 1,756 & 1,692 \\
1981 & 8,607 & 7,890 \\
1991 & 37,340 & 32,847 \\
2001 & 101,375 & 88,230 \\
2011 & 183,421 & 157,983 \\
& & \\
Growth (\%) & & \\
$1971-1981$ & 17.2 & 16.6 \\
$1981-1991$ & 15.8 & 15.3 \\
$1991-2001$ & 10.5 & 10.4 \\
$2001-2011$ & 6.1 & 6.0 \\
$1971-2011$ & 12.3 & 12.0 \\
\hline Source: Author's calculation from Statistik Listrik, \\
\multicolumn{2}{c}{ various issues }
\end{tabular}

Table 4: Electricity Indicator Between Java and Outside Java in 2011

\begin{tabular}{lrrr}
\hline Indicators & Java & Outside Java & Indonesia \\
\hline Installed Capacity (MW) & $22,514(77 \%)$ & $6,755(23 \%)$ & 29,268 \\
Net Production (GWh) & $134,232(74 \%)$ & $46,437(26 \%)$ & 180,669 \\
Energy Sold (GWh) & $117,593(74 \%)$ & $40,399(26 \%)$ & 157,993 \\
Electrification Ratio (\%) & 63.98 & 76.02 & 71.23 \\
\hline Source: PLN Statistics 2011 & &
\end{tabular}

other sector. The value of $\mathrm{BL}$ and FL for electricity which is above one, suggests that electricity is the key sector for the Indonesian economy. In terms of output multiplier, the figure showed that if final demand on electricity sector increases by Rp1 million rupiah, total output of the economy will increase by Rp1.93 million. In line with Adam's findings (2012), by relying on Cobb-Douglass production function model, Situmorang (2012) indicated that elasticity of electricity to economic growth in North Sumatera was about $0.77 \%$, higher than that of road, water, and irrigation. This suggets that, all other things being equal, $1 \%$ growth in electricity production will increase economic growth by $0.77 \%$.

\subsubsection{Structure of Electricity Production and Consumption}

There are two main players of power supply, namely PT PLN (Persero) and independent power producer (IPP). Between 2004 and 2011, share of PT PLN (Persero) to total Indonesia's electricity production only decreased slightly from $80.1 \%$ to $77.8 \%$, while share of IPP increased marginally from $19.9 \%$ to $22.2 \%$. This suggests that PT PLN
(Persero) still dominates the structure of Indonesia's power generating system (Table 6).

Although PT PLN (Persero) has currently dominated the structure of Indonesia's electricity production, this structure may change in the future. This is because, according to PT PLN (Persero)'s business plant of 2011-2020, new investment from IPP would be encouraged to reach about $43.3 \%$ of Indonesia's electricity production by 2020 . Sambodo (2012) showed that in Java-Bali system, share of IPP can reach $50 \%$ in 2020.

Encouraging IPP to increase its role in power generating may help Indonesia to increase power supply. This is because maintaining PT PLN (Persero) as a dominant player in producing electricity created various negative consequences to accelerate improvement in electricity supply. As one of state owned enterprise (SOEs), the government frequently intervene PT PLN (Persero). Most government intervention lean back not only on economic motivations, but also on political and social consideration. These government interventions hamper PT PLN (Persero) to run its business activities efficiently and effectively, which in turn reducing the capability of PT PLN (Persero) to accelerate im- 
Table 5: Electrification Ratio in Indonesia, in 2011, by Province

\begin{tabular}{|c|c|c|}
\hline Province & Electrification Ratio (\%) & Consumption per Papita (KWh) \\
\hline Nanggroe Aceh Darussalam & 87.2 & 343.5 \\
\hline Sumatera Utara & 80.1 & 548.8 \\
\hline Sumatera Barat & 76.2 & 489.8 \\
\hline Riau & 54.8 & 411.4 \\
\hline Kepulauan Riau & 76.6 & 620.1 \\
\hline Sumatera Selatan & 65.2 & 390.2 \\
\hline Jambi & 32.7 & 332.6 \\
\hline Bengkulu & 64.5 & 283.4 \\
\hline Bangka-Belitung & 66.2 & 424.3 \\
\hline Lampung & 61.9 & 315.4 \\
\hline Kalimantan Barat & 64.9 & 323.9 \\
\hline Kalimantan Selatan & 74.0 & 397.0 \\
\hline Kalimantan Tengah & 53.0 & 288.9 \\
\hline Kalimantan Timur & 61.5 & 601.3 \\
\hline Sulawesi Utara & 78.0 & 429.6 \\
\hline Gorontalo & 67.4 & 222.5 \\
\hline Sulawesi Tengah & 62.0 & 214.1 \\
\hline Sulawesi Selatan & 72.0 & 400.0 \\
\hline Sulawesi Tenggara & 51.1 & 193.6 \\
\hline Sulawesi Barat & 33.6 & 127.4 \\
\hline Maluku & 61.8 & 213,5 \\
\hline Maluku Utara & 53.5 & 192.4 \\
\hline Papua & 30,8 & 174.3 \\
\hline Papua Barat & 54.3 & 386.5 \\
\hline Bali & 68.6 & 811.1 \\
\hline NTB & 47.2 & 184.2 \\
\hline NTT & 34.5 & 101.6 \\
\hline Jawa Timur & 73.7 & 637.3 \\
\hline Jawa Tengah & 78.9 & 472.3 \\
\hline Yogyakarta & 77.4 & 535.5 \\
\hline Jawa Barat & 70.5 & 776.9 \\
\hline Banten & 55.3 & $1,176.1^{*}$ \\
\hline DKI Jakarta & $103.5^{\star \star}$ & $2,419.1$ \\
\hline Indonesia & 71.2 & 655.2 \\
\hline \multicolumn{3}{|c|}{$\begin{array}{l}\text { Note: }{ }^{*} \text { Tangerang is included in DKI Jakarta. } \\
{ }^{*} \text { Electrification ratio in Jakarta was above } 100 \% \text {, this indicates that number of } \\
\text { residential customers is larger than number of residential. The possible } \\
\text { explanation is that one resident have more than one accounts of electricity } \\
\text { due to owner rents parts of his property to several people. }\end{array}$} \\
\hline
\end{tabular}

provement in electricity supply. For example, in determining the price of electricity, PT PLN (Persero) has no room to set the price by itself. Indeed, according to Electricity Law No 30/2009, instead of PT PLN (Persero), it is central and local government who have the authority to design and approve the price of electricity and the network renting cost.

In determining the electricity price, central government has to propose, consult and obtain approval from the Parliament (Dewan Perwakilan Rakyat/DPR). Likewise, the local government has to propose, consult and obtain approval from the regional parliament (Dewan Perwakilan Rakyat Daerah/DPRD). The problem is that when the gov- ernment propose and consult the electricity price to the Parliament, its mechanism tended to be more political rather than economic in its character. Therefore, the process of determining electricity price took a long time and frequently ignored economic rationality.

The fact that the price of electricity ignored economic rationality is well indicated from the condition where, according to PT PLN (Persero)'s statistics of 2011, average price sold was about $\mathrm{Rp} 714.24 / \mathrm{kWh}$, while average operating cost was Rp1,051.14/kWh. As shown in Table 7, generating cost depends on type of power generators. Diesel and gas turbine that use oil had the highest gener- 
Table 6: Structure of Indonesian Electricity Production, 2004-2011

\begin{tabular}{cccc}
\hline Tahun & PLN (\%) & Non-PLN (\%) & Total Production (GWh) \\
\hline 2004 & 80.1 & 19.9 & 120,162 \\
2005 & 79.5 & 20.5 & 127,370 \\
2006 & 78.5 & 21.5 & 133,109 \\
2007 & 78.1 & 21.9 & 142,440 \\
2008 & 79.0 & 21.0 & 149,437 \\
2009 & 77.8 & 22.2 & 154,838 \\
2010 & 77.6 & 22.4 & 169,786 \\
2011 & 77.8 & 22.2 & 183,421 \\
\hline Source: PLN, Statistik Listrik in Various Years
\end{tabular}

Table 7: Average Generating Cost per kWh in 2011

\begin{tabular}{lrrrrrr}
\hline \multirow{2}{*}{ Generation Type } & \multicolumn{5}{c}{ Average Generating Cost per kWh (Rp/kWh) } & \multirow{2}{*}{ Total } \\
\cline { 2 - 6 } & Fuel & Maintenance & Depreciation & Others & Personnel & \\
\hline Hydro & 21.00 & 28.42 & 82.26 & 4.76 & 17.35 & 155.79 \\
Steam & 499.50 & 19.23 & 60.72 & 2.31 & 6.71 & 588.47 \\
Diesel & $2,358.36$ & 452.29 & 152.30 & 17.76 & 88.86 & $2,536.85$ \\
Gas Turbine & $2,094.86$ & 72.54 & 82.14 & 2.39 & 9.03 & $2,260.96$ \\
Geothermal & 706.36 & 7.06 & 62.54 & 1.82 & 14.83 & 792.61 \\
Combine cycle & 876.52 & 27.70 & 50.64 & 2.53 & 3.20 & 960.58 \\
\hline Total & 935.58 & 39.35 & 63.75 & 3.05 & 9.42 & $1,051.14$ \\
\hline Source: PLN (2011) & & & & & &
\end{tabular}

ating cost. The fuel cost component has important element for fossil base power generator while in the case of hydro power, the component of depreciation and maintenance had the highest share. This suggests that cost of electricity is much higher than that of its revenue. As a result, in 2011, government provided electricity subsidy for about Rp93 trillion. In addition, this situation has an adverse impact on PT PLN (Persero)'s capacity for self financing in promoting new investments in electricity infrastructure, increasing power production, and improving quality of power supply accross the country (Bappenas 2011).

Furthermore, the fact that the price of electricity is still much lower than that of its production cost resulted in PT PLN (Persero) frequently associated as financially not feasible to seek commercial loan from financial institution. This in turn reduced financial capability of PT PLN (Persero) to develop and modernize its electricity infrastructure. Consequently, PT PLN (Persero) could only maintain the existing generators and transmissions-distribution infrastructure. However, due to the ageing of many PT PLN (Persero)'s generators and transmissionsdistribution infrastructure, their efficiency and productivity tend to decline. Thus, as Dody and Yuan (2008) pointed out, the existing capacity of PT PLN
(Persero)'s generators and its transmission and distribution facilities has not been adequate to support rapid increase in power demand.

Based on the aforementioned discussion, it is necessary for the government to encourage private sector to participate in the development of power sector, particularly those in non-oil power plants such as steam coal, gas and geothermal. To this end, the government should support PT PLN (Persero)'s business plan, which state that between 2011 and 2020, the share of private sector to the Indonesia's electricity production will be increased from the current level of $22.2 \%$ to $43 \%$ by 2020.

In regard to the types of power generator and energy used, there has been an indication that PT PLN (Persero) succed to promote energy diversification and reduce its dependency away from oil. In one hand, share of diesel power plant (PLTD) to PT PLN (Persero)'s electricity production decreased from about $13.6 \%$ in 2004 to about $8.8 \%$ in 2011. On the other hand, share of steam coal power plant increased from about $32.2 \%$ in 2004 to about $41.2 \%$ in 2011 (Table 8 ). This suggests that steam coal becomes the backbone that dominate the structure of Indonesia's power system. 
However, the total share of renewable energy such as hydro-power and geothermal decreased from about $16.7 \%$ in 2004 to about $13.5 \%$ in 2011 . We also calculate the share of rated capacity to installed capacity ${ }^{4}$. We firstly expect that rated capacity is equal to installed capacity to indicate that PT PLN (Persero) can consistently maintain good conditions of power plants. However, the ratio declined from about 0.89 to about 0.87 between 2004 and 2011 which indicates that existing plants cannot operate optimally as compared with the situation in 2004. This might due to some reasons, such as lack in maintenance, technical failure, and aging.

Moreover, there are some problems due to primary energy shift from oil to coal. Most coal deposits are located in Sumatera and Kalimantan, while the majority of steam coal power plants are located in Java. There is a high risk of disruption on shipment due to high tide, particularly during bad weather. Accordingly, coal shortage during bad weather cannot be avoided, and this in turn affected negatively the quality of power supply. This suggests that PT PLN (Persero) should improve its capability to manage coal storage properly to anticipate bad weather that occur repeatedly every year.

PT PLN (Persero) also faces the difficulty to obtain coal with high energy grade. Government regulation on domestic market obligation of low energy grade coal to be allocated for PT PLN (Persero) has contributed to this difficulty. For example, based on the Ministry of Energy and Mineral Resources/MEMR Declare No. 1991 $\mathrm{K} / 30 / \mathrm{MEM} / 2011$, about 82.07 million tons of coal needs to be provided for the domestic market in 2012 and the share of PT PLN (Persero) and IPP is about $57.2 \%$ and $10.76 \%$, respectively. The regulation stated that this amount is about $24.72 \%$ from national coal production. PT PLN (Persero) is directed to consume low energy grade coal with calorie value of $4,200 \mathrm{kcal} / \mathrm{kg}$ (lignite), while a high energy grade coal is mostly allocated for industry with calorie value of (sub-bituminous) 5,100 $\mathrm{kcal} / \mathrm{kg}$. Dody and Yuan (2008) argued that when PT PLN (Persero) used low energy grade coal, it is

\footnotetext{
${ }^{4}$ Installed capacity is maximum capacity and rated capacity is actual capacity that can be generated. Rated capacity is lower or equal than installed capacity because due to technical problems, installed capacity cannot be fully attained.
}

highly unlikely that the installed capacity would be reached optimally.

Table 8 also indicates the decline in the share of hydro-power to PT PLN (Persero)'s power production. A key informant from PT PLN (Persero) argued that degradation in forest and watershed environment is responsible for the decline. Degradation in the environment reduced significantly water catchment in PT PLN (Persero)'s dams. Without designing systematic and wise efforts to maintain and increase quality of forests and watershed environment, it will be highly likely that the decline in the share of hydropower to PT PLN (Persero)'s power production occur continuously in the future. Collaboration among PT PLN (Persero) and other stakeholders, such as central and local government, community, and non government organizations, is urgently required to maintain and increase the quality of the environment.

In addition to the decline in the share of hydropower, PT PLN (Persero) face other problems to improve its capability in providing electricity. First, in 2011, the transmission and distribution loss reached about $9.54 \%$ that decreased substantially from about $16.88 \%$ in 2003 (PT PLN (Persero), 2011). In 2011 share of transmission and distribution to total loss was about $2.25 \%$ and $7.34 \%$ respectively. Several technical factors that contribute to high level of loss ratio are, such as malfunction of meter equipments, unstandardized meter equipments, and stealing. Due to high transmission and distribution loss, PT PLN (Persero) cannot optimize its revenue that is necessary to increase power investment.

Second, PT PLN (Persero) has high arrears payments from its customers. In 2011, the arrears payment reached $\mathrm{Rp} 3$ trillion. There are three types of customer who are arrears in paying their electricity bill to PT PLN (Persero), namely common households Rp1.9 trillion, Indonesian Armed Forces Rp842.1 billion, Non-Indonesian Armed Forces Rp79.2 billion, local government Rp158.3 billion, and state owned enterprises Rp7.7 billion. The important point here is that high arrears payment has an adversed impact on the cash flow of PT PLN (Persero).

Third, the structure of its customer also affects financial capacity of PT PLN (Persero) negatively. Households become dominant player in terms of number of customer and electricity sold. In 2011, 
Table 8: PT PLN (Persero)'s Installed Capacity by Type of Generator (\%), 2004-2011

\begin{tabular}{|c|c|c|c|c|c|c|c|c|}
\hline Tahun & 2004 & 2005 & 2006 & 2007 & 2008 & 2009 & 2010 & 2011 \\
\hline PLTA & 14.9 & 14.3 & 14.2 & 13.9 & 13.7 & 13.7 & 13.3 & 12.0 \\
\hline PLTU & 32.2 & 30.6 & 33.1 & 33.8 & 34.2 & 34.2 & 31.5 & 41.2 \\
\hline PLTG & 6.9 & 12.1 & 11.0 & 11.0 & 9.8 & 10.0 & 12.1 & 9.7 \\
\hline PLGU & 30.6 & 27.9 & 28.3 & 27.8 & 28.8 & 28.8 & 26.2 & 26.8 \\
\hline PLTP & 1.8 & 1.8 & 1.6 & 1.6 & 1.6 & 1.6 & 1.7 & 1.5 \\
\hline PLTD & 13.6 & 13.2 & 11.8 & 11.7 & 11.8 & 11.6 & 15.1 & 8.8 \\
\hline PLTMG & 0.1 & 0.1 & 0.0 & 0.0 & 0.1 & 0.1 & 0.1 & 0.1 \\
\hline PLTMH & 0.0 & 0.0 & 0.0 & 0.0 & 0.0 & 0.0 & 0.0 & 0.0 \\
\hline PLTS & 0.0 & 0.0 & 0.0 & 0.0 & 0.0 & 0.0 & 0.0 & 0.0 \\
\hline PLT Bayu & 0.0 & 0.0 & 0.0 & 0.0 & 0.0 & 0.0 & 0.0 & 0.0 \\
\hline Total (MW) & $21,460.4$ & $22,515.1$ & $24,846.2$ & $25,223.9$ & $25,594.9$ & $25,636.7$ & $26,547.9$ & $29,285.6$ \\
\hline
\end{tabular}

Table 9: Structure of Power Consumption, 2004-2011

\begin{tabular}{lrrrrr}
\hline & Industry & Commercial & Public & Household & Total (GWh) \\
\hline Share (\%) & & & & & \\
2004 & 38.0 & 20.0 & 5.6 & 36.4 & 106,024 \\
2005 & 39.7 & 15.9 & 6.0 & 38.5 & 107,032 \\
2006 & 38.7 & 16.4 & 6.1 & 38.9 & 112,610 \\
2007 & 37.8 & 17.0 & 6.2 & 39.0 & 121,247 \\
2008 & 37.2 & 17.8 & 6.2 & 38.9 & 129,019 \\
2009 & 34.3 & 18.4 & 6.4 & 40.8 & 134,581 \\
2010 & 34.6 & 18.4 & 6.3 & 40.6 & 147,297 \\
2011 & 34.6 & 17.9 & 6.2 & 41.2 & 157,992 \\
Growth (\%) & & & & & \\
$2004-2011$ & 4.5 & 4.2 & 7.5 & 7.8 & 5.9 \\
\hline Source: PT PLN (Persero) Statistics 2011 &
\end{tabular}

total number of PT PLN (Persero)'s costumers was about $45,895,145$ in which $92.8 \%$ of them is households. In addition, in 2011, households consumed $41.2 \%$ of PT PLN (Persero)'s total electricity sold. The problem is, unlike in other countries, due to political interest, electricity tariff that PT PLN (Persero) apply for household is much lower than those for other customers, such as industrial sector. Such a mechanism in determining tariff for household resulted in PT PLN (Persero)'s difficulty in maintaining and increasing its income, and these in turn reduced the capability of PT PLN (Persero) to maintain and develop new investment in electricity infrastructure.

Between 2004 and 2011, the household electricity consumption grew by $7.5 \%$ per year, higher than those in other sector (Table 9). If the pricing policy is unchanged, rapid increase in the household electricity consumption might worsen PT PLN (Persero)'s financial position. As a result, PT PLN
(Persero) will be pushed down to play its role in maintaining and developing electricity infrastructure required to increase electricity supply.

Furthermore, maintaining current electricity pricing policy may add to the government fiscal burden. Rapid increase in the household electricity consumption may push the government to allocate a higher subsidy on electricity. Actually, between 2000 and 2011, the growth of electricity subsidy reached about 33,1\% per year, much higher than total government spending growth of only $17.4 \%$ per year. Accordingly, share of electricity subsidy to total government spending rise considerable from $1.8 \%$ in 2000 to $7 \%$ in 2011 (Table 10).

The rapid increase in the electricity subsidy will abolish fiscal capacity of the government to maintain and develop electricity infrastructure. The capacity to create demand- and supply-side investment will improve if the government gradually 
switches the electricity subsidy from the final consumer to the upstream level. Without developing electricity infrastructure, it will be highly unlikely that Indonesia could succeed to deal with the problem of electricity shortage. Adjustment in the electricity tariff may improve financial capability of both PT PLN (Persero) and the government.

According to PT PLN (Persero)'s business plan of 2012-2021, total investment for developing generator, transmissions and distribution is about US $\$ 64.9$ billion. It is difficult for PLN to finance the investment. Currently, source of investment funds are supported by two step loan, bond issue, multilateral debt (IBRD and ADB), and bilateral loan (JICA and AFD). Therefore, it is necessary to adjust electricity tariff on the basis of the economic rationality (cost recovery principles). However, reducing electricity subsidies needs to be done gradually to provide time for producers and costumers to upgrade and prepare their infrastructure, while government will also have time to improve its personnel skills and managerial capacity. As Victor in 2009 (as cited in Bazilian \& Onyeji 2012) argued, 'serious reforms involve not only reducing subsidy demand but also augmenting the government's ability to put in place alternative policies that would be more cost-effective'.

\subsection{Public Private Partnership in Elec- tricity Sector}

The previous analysis pointed to three major problems that the electricity sector has to deal with. First, electricity supply cannot meet its demand due to poor development in electricity infrastructure. Second, electricity pricing policy ignored economic rationality, which in turn resulted in the rapid increase in electricity subsidy and the reduction in the government's fiscal capacity to maintain and develop electricity infrastructure. Third, electricity pricing policy also aggravate PT PLN (Persero)'s financial capacity for self financing in promoting new investments in electricity infrastructure.

Public Private Partnership (PPP) program could be the main effective means to promote investment in electricity infrastructure in Indonesia. However, it is important to note that PPP will work effectively if the government can provide substantial reform for pricing policy. Thus, the government should change its approach in treating and providing electricity. It means that the government should start introducing proper pricing mechanism which should underpin the treatment of investments in electricity infrastructure.

By introducing proper pricing mechanism, the government treats electricity as scarce economic goods. Thus, all consumers, directly or indirectly, should pay the right price for it. By pricing electricity rightly, the government applies economic instrument to affect behavior towards maintenance and efficient electricity usage, to provide incentives for demand management and ensure cost recovery, and to signal consumers' willingness to pay for additional investment in electricity infrastructure (Queensland Competition Authority 2003).

To begin with introducing proper pricing mechanism, the government should have strong commitment to reform electricity subsidy policy. As seen from Figure 5, about $51 \%$ of electricity subsidy benefits the low voltage customers that is about 31.2 million customers. Industrial sector also enjoys electricity subsidy that is about $24.5 \%$ of total subsidy. Electricity tariff, that both the low voltage customers and industrial sector pay, is much lower than the average operating cost to produce electricity that they enjoyed.

In regard to the implementation of PPP, since 2007, the government has introduced PPP to encourage private sector to participate in the provision and development of electricity infrastructure. To carry out this program, the Indonesian government has taken several important actions. Indonesia Infrastructure Summit held several times to socialize, promote, and attract private sector to involve in PPP. Some institutions, such as PT Sarana Multi Infrastructure (SMI) and PT Indonesia Infrastructure Assurance (PII), formed to strengthen the implementation of PPP. In addition, some of the rules issued and several incentives offered to attract participation of private sector in PPP (Adam 2012).

Unfortunately, the government's efforts to stimulate private sector to engage in the development of electricity infrastructure have been less successful. The development of electricity infrastructure through PPP program takes place in a relatively slow motion, suggesting that response of the private sector to participate in the development of electricity infrastructure through PPP program has 
Table 10: Electricity Subsidy and State Expenditure, 2000-2011

\begin{tabular}{cccc}
\hline Year & $\begin{array}{c}\text { Electricity Subsidy } \\
\text { (Trillion Rp) }\end{array}$ & $\begin{array}{c}\text { State Expenditure } \\
\text { (Trillion Rp) }\end{array}$ & $\begin{array}{c}\text { Electricity Subsidy/ } \\
\text { State Expenditure (\%) }\end{array}$ \\
\hline 2000 & 3.9 & 221.5 & 1.8 \\
2001 & 4.6 & 341.6 & 1.3 \\
2002 & 4.1 & 322.2 & 1.3 \\
2003 & 3.8 & 376.5 & 1.0 \\
2004 & 2.3 & 427.2 & 0.5 \\
2005 & 8.9 & 509.6 & 1.7 \\
2006 & 30.4 & 667.1 & 4.6 \\
2007 & 33.1 & 757.6 & 4.4 \\
2008 & 83.9 & 985.7 & 8.5 \\
2009 & 49.5 & 937.4 & 5.3 \\
2010 & 57.6 & 1042.1 & 5.5 \\
2011 & 90.4 & 1295.0 & 7.0 \\
\hline Source: Ministry of Finance (Basic Data of APBN - Various Year)
\end{tabular}

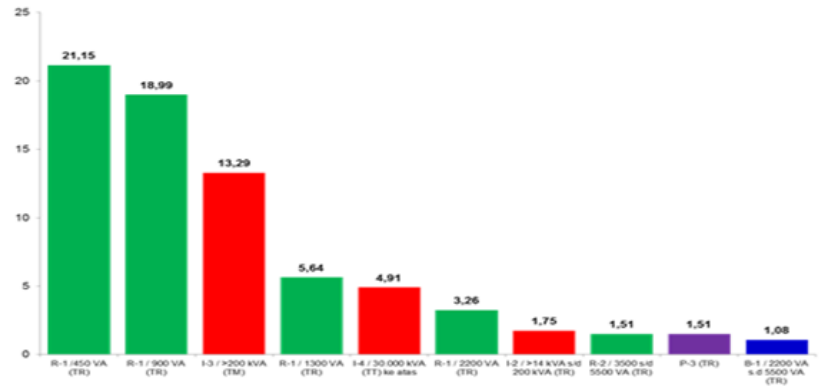

Figure 5: Top 10 Receivers of Electricity Subsidy in 2013 (in Trillion Rupiah)

been weak. Between 2010 and 2014, the government set its target to offer six electricity infrastructure projects with total project value of USD 8.045 billion (Bappenas 2011). Yet, up to the end of 2012, the government was only able to tender one project, namely the Central Java Coal Fired System Power Plant (CJCFSPP). This project is based on steam coal prower plant, located in Batang, Central Java. The total investment of this project is about USD 4 billion and the new power plan has capacity of $2 \times 1,000 \mathrm{MW}$. This is the first project that use ultra supercritical technology or advanced technology that is more efficient and has low $\mathrm{CO} 2$ emissions. The power plant is expected to operate in 2017.

The tender winner for the CJCFSPP project is a consortium of Japan-based Electric Power Development (J-Power) with 34\% share, Adaro Energylocal coal mining with $34 \%$ share, and the Japanbased Itochu Corporation with $32 \%$ share. To run its daily business, in June 2011, the consortium established PT Indonesia Power Bhi- masena. Furthermore, in early October 2011, PT Bhimasena signed purchasing agreement with PT PLN (Persero). According to the contract agreement, PT Bhimasena is responsible to supply electricity to PT PLN (Persero) for about 25 years.

Unfortunately, PT Bhimasena failed to run the project according to its planned time line. Ground breaking for the project site was initially expected to starting in October 2012. However, due to various problems, the ground breaking was delayed up to October 2013. As a result, there will be a delay on project complishment.

Adam (2012) identified various factors that made PT Bhimasena failed to run the project according to its planned time line. First, the feasibility study, including assessment on environmental impact (AMDAL) of the CJCFSPP project, has not yet been completed. This is an indication that electricity infrastructure projects that are offered to private sector are not well prepared. This could be because the PJPK (Penanggung Jawab Proyek 
Kerjasama - the agency in charge of partnership projects) in the Ministry/Non-Ministerial Government Agency/Local Government/State Owned Enterprises/Regional Owned Enterprises, have not had experiences on how to prepare the projects to be offered to private sector.

There has been a strong indication that the PJPK is more used to prepare projects to be funded by the state budget (APBN) or the regional government budget (APBD). Thus, considering the high cost of consultants to conduct the feasibility study, the feasibility study by PJPK are just done carelessly instead of being technically competent. In addition to technical matters, the feasibility study document that the private sector needs should include information on various issues related to legal, economic, financial and risk issues, and the provision of government incentive schemes, and problems that may arise when the private sector involved in PPP projects.

Second, the government has issued Law No. 2/ 2012 on land procurement for public infrastructure. However, in practice, the law has not yet been implemented effectively. Accordingly, PT Bhimasena still need to struggle with land clearing. Negotiation with local community nearby the power site run slowly. In sum, PT Bhimasena remained to face high risk, uncertainty, and costs to be incurred when PT Bhimasena has to deal with land acquisition. This suggests that Law No. 2/ 2012 might be necessary to provide legal aspect for land procurement. Yet, it is insufficient to accelerate land acquisition effectively. Therefore, this law should be supported by implementing regulation to provide more technical aspect of land acquisition, particularly in relation to land price, required time to proceed land clearing, and job description among multiple government agency (central, provincial, and local governments) to involve in land procurement.

Third, public resistance to the construction of Power Plant is quite high. Resistance is not only limited to residents' reluctance to sell their land, but it also lead to things that are anarchists. For example, on 29 September 2012, the staffs of Sumitomo Mitsui Banking Corp who are Japanese and the driver (Indonesian) that aim to conduct feasibility study have been taken hostage by local people. Public resistance could be attributed to their mis-perception in understanding the impact of the presence of Power Plant. The important point here is that the PPP has not been supported by the government's guarantee where private sector could receive financial guarantee for the delay caused by slowness in land acquisition or protest by the residents.

Fourth, the three problems explained earlier resulted in the CJCFSPP project becomes high risk and uncertain project. High risk and uncertainty force PT Bhimasena to face the difficulties to seek commercial loan, accounted for about USD 3 billion or $75 \%$ of total project investment. Negotiation among PT Bhimasena and several banks, such as Sumitomo Mitsui Banking Corp did not run smoothly. The bank asked PT Bhimasena to minimize risks and uncertainty that is important to make the project financially feasible. However, PT Bhimasena could not handle the problems completely as the problems are, on several counts, outside the control of PT Bhimasena. Without any support from the central and local governments as well as the public, it will be highly unlikely for PT Bhimasena to be able to minimize risk and uncertainty. Hence, it is necessary for PT Bhimasena, the government, and the public to have cooperation and share the same vision.

From policy point of views, the government has to be concerned with the successful development of the CJCFSPP project. In comparison with five other power generator infrastructure projects, the CJCFSPP project is more strategic in that the value of the project and the capacity of the electricity generated are much greater. For example, South Sumatera 9 and 10 projects is expected to add capacity of only about $650 \mathrm{MW}$. Thus, government needs to provide full supports on this project. The successful development of the CJCFSPP project will significantly improve the interest of private sector to participate in the development of electricity infrastructure in Indonesia.

Based on the above discussion, in addition to address the four aforementioned impediment factors, the government need to focus on promoting PPP by preparing electricity pricing reform to reflect cost of service. Simultaneously, the government needs to reduce electricity subsidy gradually and to design subsidy mechanism for poor-targeted only. 


\section{Conclusion}

This paper has analyzed the performance of electricity sector in Indonesia. The analysis indicated that electrification ratio and electricity consumption per capita in Indonesia is relatively low compare with those in other middle income economies, suggesting that Indonesia failed to provide sufficient electricity supply. Poor development in electricity infrastructure is responsible for this insufficient electricity supply. Hence, Indonesia needs to maintain and develop new electricity infrastructure to increase its electricity production. The environment also need to be taken as one of electricity development goals.

Unfortunately, various policy measures, such as pricing policy that ignored economic rationality and relied on the government subsidy, has resulted in the reduction in both PT PLN (Persero)'s and the government fiscal capacity to develop electricity infrastructure. Consequently, PT PLN (Persero) could only maintain, operate, and rely on its existing electricity infrastructure. The problem is that due to many of PT PLN (Persero)'s electricity infrastructure ageing, their efficiency and productivity tend to decline. Thus, the existing capacity of PT PLN (Persero)'s infrastructure has not been adequate to support rapid increase in electricity demand.

Reform on pricing policy is necessary condition to improve financial capacity of PLN and for better allocation of electricity subsidy. Reducing electricity can improve fiscal space and this can enhance government capacity for public investment such rural electrification program. Although, PPP can be one of solutions to promote investment, the program has not successfully operated. To carry out this program, the government has taken various steps. Unfortunately, these various steps have not given satisfactory results. Between 2010 and 2014, the government has set its target to offer 6 electricity infrastructures with the value of USD 8,045 billion. However, up to the end of 2012, the government was only able to tender one project, namely the Central Java Coal Fired System Power Plant (CJCFSPP project).

This is not the end of the story. Ground breaking of the CJCFSPP project has been delayed up to October 2013 due to several reasons. First, poor preparation in the project's feasibility documents, including assessment on environmental impact (AMDAL) for the private sector. Second, slow movement in land acquisition. Third, high public resistance to the construction of the project. Fourth, perception on the CJCFSPP project as hig risk and uncertain project resulted in the winning bidder (PT Indonesia Power Bhimasena) faces the difficulty to seek commercial loan from financial institutions.

The CJCFSPP project is the first pilot project on the basis of PPP scheme in the power sector. If the project can be executed successfully, it will have a high leverage factor to improve investment climate in the power sector. Thus, all the aforementioned problems should be addressed carefully by the government to attract more private sector engagements in the development of electricity infrastructure.

\section{References}

[1] Adam, L. 2012, 'The Roles and Problems of Infrastructure in Indonesia', Economics and Finance in Indonesia, vol. 60, no. 1, pp. 105-126.

[2] Arief, Z 2011, 'Pelaksanaan Tender dalam Pembangunan Infrastruktur'. Paper presented at the Conference on Seminar Hukum Nasional, July 20, Jakarta.

[3] Bappenas 2011, PPP Book, Bappenas, Jakarta

[4] Bergsten, CF, Charles, F, Nicholas, RL \& Dereck, JM 2009, 'Energy Implications of China's growth' in China's Rise: Challenges and Opportunities. Retrieved October 8, 2009, from Peterson Institute for International Economics, http://bookstore.piie.com/book-store/4341.html.

[5] Bhalla, MS 2000, 'Transmissions and Distribution Loss (Power)', in Proceedings of the National Conference on Regulation in Infrastructure Services: Progress and Way Forward, November 14-15, New Delhi, India.

[6] Dody, BP \& Yuan, BH 2008, Masalah yang Dihadapi PLN. http://agguss.wordpress.com/2008/06/24/9masalah-yang-dihadapi-pln/. [16 October 2012].

[7] Hu, Z, Yuan, J \& Hu, Z 2011, 'Study on China's Low Carbon Development in an Economy-Energy-ElectricityEnvironment Framework', Energy Policy, vol. 39, pp. 2596-2605.

[8] International Energy Agency/IEA 2003, World Energy Investment Outlook 2003. http://www. worldenergyoutlook. org/media/weowebsite/ 2008-1994/weo2003.pdf. [26 February 2013].

[9] International Energy Agency/IEA 2005, China's Power Sector Reforms: Where to Next. http: //www. iea.org/publications/freepublications / publication/chinapower.pdf. [10 September 2013].

[10] International Energy Agency/IEA 2008, Energy Policy Review of Indonesia, IEA, Paris.

[11] International Finance Corporation 2011, Doing Business 2012, International Finance Corporation, Washington. 
[12] PT PLN (Persero) 2009, Annual Report. PT PLN (Persero), Jakarta.

[13] PT PLN (Persero) 2011, Statistik Listrik, PT PLN (Persero), Jakarta.

[14] Queensland Competition Authority 2003, General Pricing Principles for Infrastructure Investments Made in Response to Extraordinary Circumstances, QCA, Brisbane.

[15] Sambodo, MT 2012, Mathematical Modeling Analysis for Investigating the Future Expansion of the Electric Power System in Indonesia. Unpublished doctoral's thesis, National Graduate Institute for Policy Studies (GRIPS), Tokyo, Japan.

[16] Sambodo, MT \& Oyama, T 2010, 'The Electricity Sector Before and After the Fast-Track Program', Economics and Finance in Indonesia, vol. 58, no. 3, pp. 285-308.

[17] Sambodo, MT \& Oyama, T 2011, 'Economic, Energy, and $\mathrm{CO} 2$ Intensity Valuation in Indonesia's Manufacturing Industry', Jurnal Ekonomi dan Pembangunan, vol. XIX, no. 2, pp. 17-29.

[18] Sambodo, MT \& Oyama, T 2011, 'Investigating Economic Growth, Energy Consumption and Their Impact on $\mathrm{CO} 2$ Emissions Targets in China', Journal of Asian Public Policy, vol. 4, no. 3, pp. 279-306.

[19] Situmorang, LS 2012, Analisis Pengaruh Pembangunan Infrastruktur Terhadap Pertumbuhan Ekonomi Provinsi Sumatera Utara. Unpublished master's thesis, UNIMED, Medan.

[20] Victor, D 2009, The Politics of Fossil-Fuel Subsidies, Global Subsidies Initiative (GSI) of the International Institute for Sustainable Development (IISD). IISD, Geneva.

[21] Wallace, W 2008, From Indonesia 2008 to Indonesia 2012 and beyond Where Things Stand and the Challenges Ahead, Washington DC.

[22] World Bank 2005, Raising Investment in Indonesia a Second Generation of Reforms, World Bank, Washington DC.

[23] World Economic Forum 2012, The Global Competitiveness Report 2012-2013, World Economic Forum, Geneva. 